\title{
Description of two new species of Rissoella Gray, I 847 (Mollusca, Gastropoda, Heterobranchia) from Venezuela, with a key to the Caribbean species known for the genus
}

\author{
Manuel Caballer ${ }^{1, \dagger}$, Jesus Ortea ${ }^{2, \ddagger}$, Samuel Narciso ${ }^{3, \S}$ \\ tion), Calle Carabobo s/n, Chichiriviche, Falcón, Venezuela \\ † urn:lsid:zoobank.org:author:9F05651B-861F-44AE-BA7C-F21A6FB99203 \\ ¥ urn:lsid:zoobank.org:author:BB6893F4-4561-4929-B35E-D9F043BF1FD3 \\ § urn:lsid:zoobank.org:author:76E740CE-8235-473F-988A-F8B84FDCB241 \\ Corresponding author: Manuel Caballer (manuelcaballergutierrez@hotmail.com)
}

I Department of Oceanology and Coastal Sciences, Venezuelan Institute for Scientific Research, Carretera Panamericana km 11, Altos de Pipe, Miranda, Venezuela 2 Department BOS, University of Oviedo, Calle Catedrático Valentín Andrés Álvarez s/n, 33006 Oviedo, Asturias, Spain 3 FUDENA (Nature Defense Founda-

Academic editor: Eike Neubert | Received 23 February 2011 | Accepted 26 May 2011 | Published 5 July 2011

urn:lsid:zoobank.org:pub:A87FE544-BD80-47D1-A1E3-0B8169D8A240

Citation: Caballer M, Ortea J, Narciso S (2011) Description of two new species of Rissoella Gray, 1847 (Mollusca, Gastropoda, Heterobranchia) from Venezuela, with a key to the Caribbean species known for the genus. ZooKeys 115 : 1-18. doi: 10.3897/zookeys.115.1163

\begin{abstract}
Two new species of the genus Rissoella Gray, 1847 are described from Venezuela, one from the National Park Morrocoy, Rissoella morrocoyensis sp. n. and the other from the Wildlife Refuge Isla de Aves, Rissoella venezolanicola sp. n. $R$. morrocoyensis sp. $\mathbf{n}$. has a deep umbilicus (partly closed), preumbilical cord, black head, hypobranchial gland marked by a pale yellow boomerang-shaped ribbon and it lives on the leaves of the seagrass Thalassia testudinum Banks \& König, 1805. R. venezolanicola sp. $\mathbf{n}$. has an angled preumbilical cord which extends to the columella delimiting a trapezoid, a hypobranchial gland marked by a yellow quaver-shaped ribbon and protoconch with fuchsia highlights. It lives on the brown alga Dictyota spp. The records of Rissoella in the Caribbean are revised and illustrations, a comparative table and a key to the Caribbean species known for the genus are provided.
\end{abstract}

\section{Keywords}

Rissoellidae, new species, Thalassia, Dictyota, Morrocoy, Isla de Aves, Southern Caribbean, Venezuela

Copyright M. Caballer et al. This is an open access article distributed under the terms of the Creative Commons Attribution License, which permits unrestricted use, distribution, and reproduction in any medium, provided the original author and source are credited. 


\section{Introduction}

The genus Rissoella Gray, 1847 consists of minute, less than $2 \mathrm{~mm}$ long gastropods, living on algae in shallow waters around the world. Their transparent shells have few distinguishing characters (Ponder and Yoo 1977), but the body exhibits pigmented organs that allow the separation of species (Ortea and Espinosa 2001; Ortea and Espinosa 2004; Rolán and Hernández 2004; Espinosa and Ortea 2009). Ponder and Yoo (1977) in the Pacific and Ortea and Espinosa (2004) in the Atlantic Ocean recognized a number of characteristic traits of the shell for identifying the different species using the proportions and the angle of the different whorls, the protoconch and especially the shape of the umbilicus, in addition to the colour of the body.

The natural history of Rissoella in western Atlantic was recently revised by Ortea and Espinosa (2004), who established 4 valid species for the area and described 7 new taxa from Cuba. Posteriorly, Rissoella aliciae Espinosa and Ortea, 2009 (Fig. 31), was added to the list. Nevertheless, the inventory of species is still incomplete. 10 species had been described in northern Caribbean, one in Central America (Tab. 1) and one in Brazil (Rissoella ornata Simone, 1995), but none in southern Caribbean, where only one species, Rissoella caribaea Rehder, 1943, has been recorded. The discovery of two members of the genus Rissoella with characters that differentiate them from other known species in the American Atlantic motivated this work.

\section{Material and methods}

The specimens were collected by snorkelling in two localities of Venezuela; the National Park Morrocoy (March 2010) and the Wildlife Refuge Isla de Aves (August 2010). A Carl Zeiss stereomicroscope was used to take data on external anatomy and color patterns. The animals were photographed alive and preserved in ethanol $96 \%$. To prevent the progressive deterioration of the shells due to ethanol, the holotypes and some of the paratypes were kept dried.

To compare with other species of the genus, diagrams were made of shell, protoconch and umbilicus using an Olympus SZ16 stereomicroscope. A caliper was used to take measurements of each specimen. For other measurements such as the angle of the spire or umbilical angle, the methodology of Ortea and Espinosa (2004) was used.

SEM images were taken using a Hitachi S-2400 at the Central University of Venezuela. As umbilicus were partially closed by the expansion of the columellar edge, they were photographed (SEM) at an oblique angle (Figs 9-12) for better observation of preumbilical cord.

Abbreviations: SOM-IVIC, Marine Organisms Section of the Biological Collections of the Venezuelan Institute for Scientific Research (Register number 028), Miranda, Venezuela; FUDENA, Nature Defense Foundation, Falcon, Venezuela; PNM, National Park Morrocoy; RFSIA, Wildlife Refuge Isla de Aves. 


\section{Systematics}

\section{Family Rissoellidae Gray, 1850}

\section{Genus Rissoella Gray, 1847}

Type species: Rissoa? glaber Alder (= Rissoella glaber (err. pro glabra) J. E. Gray, 1847; = Rissoa? diaphana Alder, 1848; = Rissoa albella Alder, 1844), by monotypy.

\section{Rissoella morrocoyensis sp. $\mathrm{n}$.}

urn:Isid:zoobank.org:act:76349EA2-0BD1-49BE-B299-975357F50CA9

http://species-id.net/wiki/Rissoella_morrocoyensis

Figs 1-5, 9-10, 13-17, Tabs 1, 2, 4

Description. Shell very small (Tab. 2), smooth, translucent and fragile (Fig. 13); protoconch about half a whorl after the nucleus (Fig. 14); teleoconch of two and a half whorls to two and three quarters, convex profile, well marked suture; aperture semicircular, columella almost straight; umbilicus small, very narrow and deep, partially closed by the expansion of the columellar edge, with a preumbilical cord (Figs 9-10, 15), average height of the last whorl, $85 \%$ of shell length; average height of the aperture, $60 \%$ of shell length (Tab. 2); shell length $/$ width ratio $=1.32$; spiral angle $=60^{\circ}$; umbilical angle $=21^{\circ}-28^{\circ}$.

Operculum semicircular, translucent amber, rather opaque in the center, $453 \mu \mathrm{m}$ long by $255 \mu \mathrm{m}$ wide in a shell of $0.92 \mathrm{~mm}$ length; inner side with a triangular projection with spearhead-shaped apex.

Head dark brown to black; black eyes set in a circular area of translucent white colour; oral lobes wider and shorter than the cephalic tentacles; both translucent, dark brown or

Table I. Valid species of the genus Rissoella Gray, 1847 in the Caribbean.

\begin{tabular}{l|c}
\hline Species & Type locality \\
\hline Rissoella caribaea Rehder, 1943 & USA \\
\hline Rissoella galba Robertson, 1961 & Bahamas \\
\hline Rissoella gandocaensis Ortea \& Espinosa, 2001 & Costa Rica \\
\hline Rissoella ameliae Ortea \& Espinosa, 2004 & Cuba \\
\hline Rissoella belkisae Ortea \& Espinosa, 2004 & Cuba \\
\hline Rissoella dianae Ortea \& Espinosa, 2004 & Cuba \\
\hline Rissoella zaidae Ortea \& Espinosa, 2004 & Cuba \\
\hline Rissoella florae Ortea \& Espinosa, 2004 & Cuba \\
\hline Rissoella elsae Ortea \& Espinosa, 2004 & Cuba \\
\hline Rissoella taniae Ortea \& Espinosa, 2004 & Cuba \\
\hline Rissoella aliciae Espinosa \& Ortea, 2009 & Cuba \\
\hline Rissoella morrocoyensis sp. $\mathrm{n}$. & Venezuela \\
\hline Rissoella venezolanicola sp. $\mathrm{n}$. & Venezuela \\
\hline
\end{tabular}




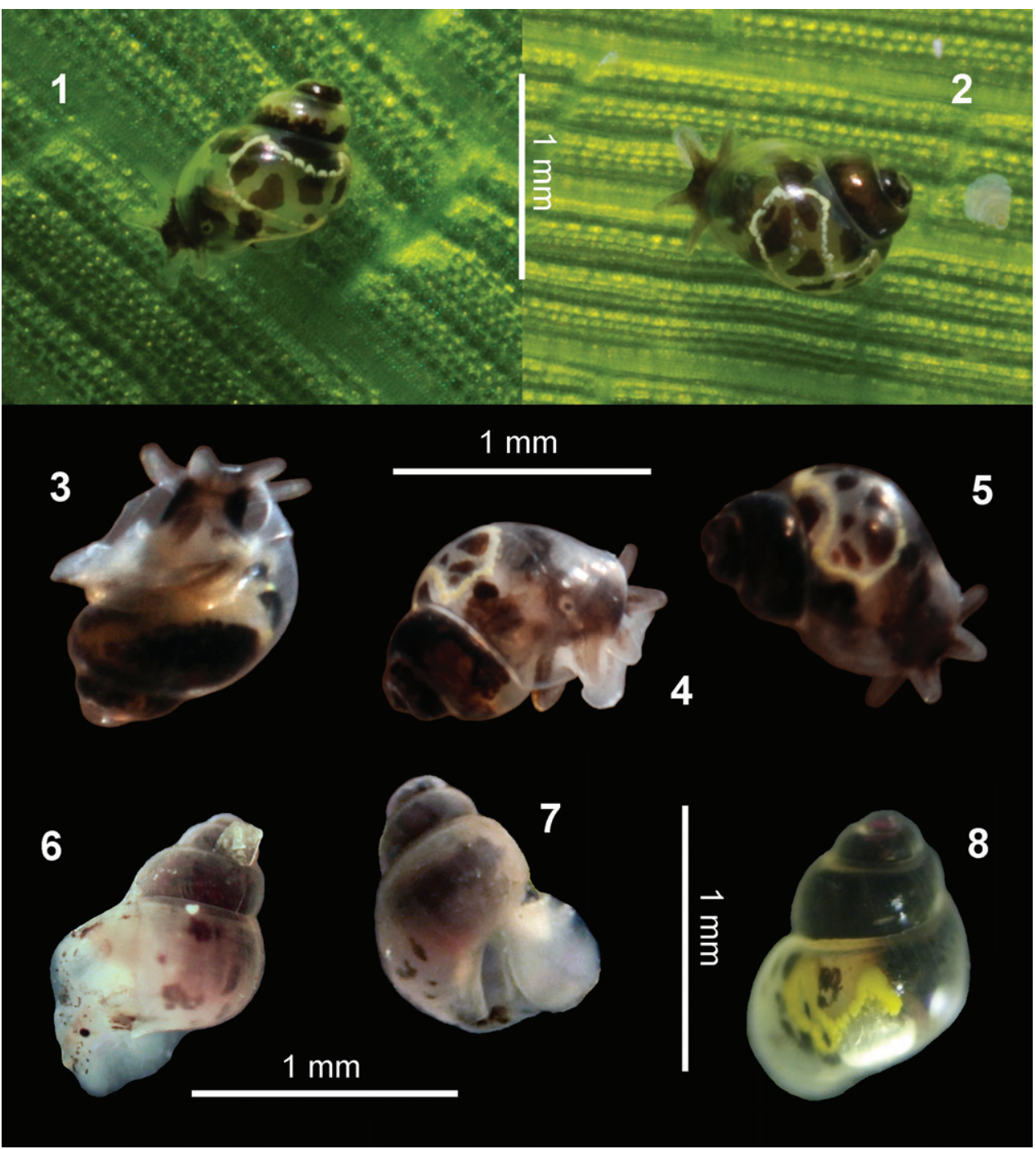

Figures I-8. Rissoella morrocoyensis sp. n. I-5: on a leaf of Thalassia testudinum (1-2), ventral view (3), lateral view (4), dorsal view (5). Rissoella venezolanicola sp. n. 6-8: lateral view (6), ventral view (7), dorsal view $(\mathbf{8})$.

black, completely or just at the base (Figs 1-2); foot slightly bilobed, with a white hyaline sole; dorsal part of the foot, white or with an irregular dark drawing (Fig. 3); flanks of the animal the same colour as the head (Fig. 4); mantle white, with several black blotches around the hypobranchial gland; hypobranchial gland translucent white, with white spots, irregular black blotches and a pale yellow band marking its boomerang-shaped contour with no transversal bands (Fig. 5); visceral mass in the first whorls, dark brown to black.

Odontophoral cartilages rectangular, with polygonal uncini of 10-16 $\mu \mathrm{m}$ long, regularly imbricated (Fig. 16); radular formula of a specimen $1.02 \mathrm{~mm}$ shell length, 


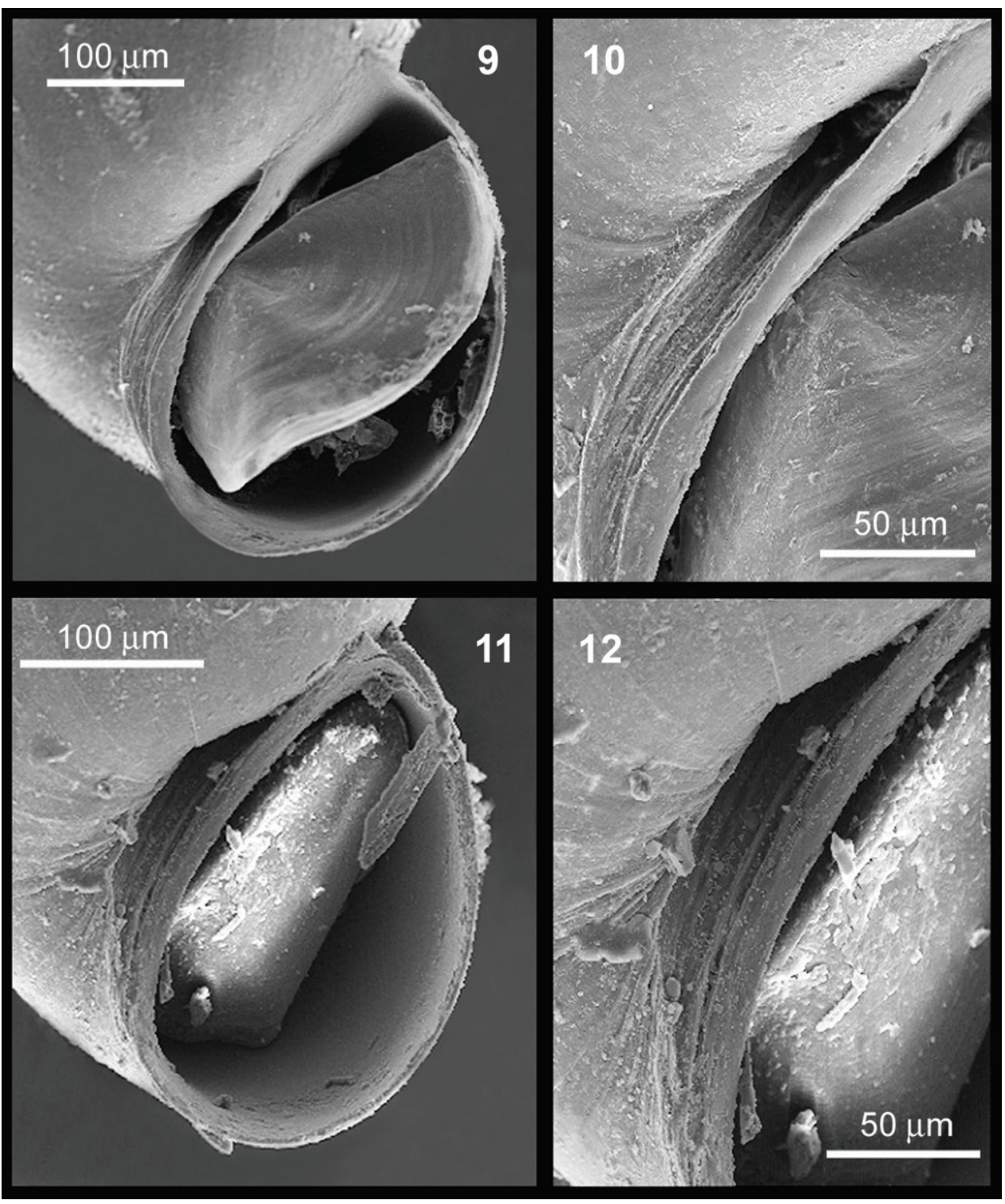

Figures 9-12. Rissoella morrocoyensis sp. n. 9-10: view of the aperture and the umbilicus (9) detail of the umbilicus (I0). Rissoella venezolanicola sp. n. I I-I 2: view of the aperture and the umbilicus (II), detail of the umbilicus $\mathbf{I 2}$.

$15 \times$ 1.1.R.1.1; rachidian tooth wide, with bilobed apex forming two smooth cusps (Fig. 17), slightly shorter than marginal tooth; lateral tooth thorn-shaped, $34.2 \mu \mathrm{m}$ long, with the apex hooked and smooth, imbricated with the opposite tooth above the rachidian; marginal tooth triangular, $26.1 \mu \mathrm{m}$ long, with sharp apex.

Types. Holotype, $1.06 \mathrm{~mm} \times 0.82 \mathrm{~mm}$, collected alive (June 10, 2010), preserved dry and deposited in SOM-IVIC (IVICCMT005). Paratypes 1-2, $1.25 \mathrm{~mm} \times 0.86$ 


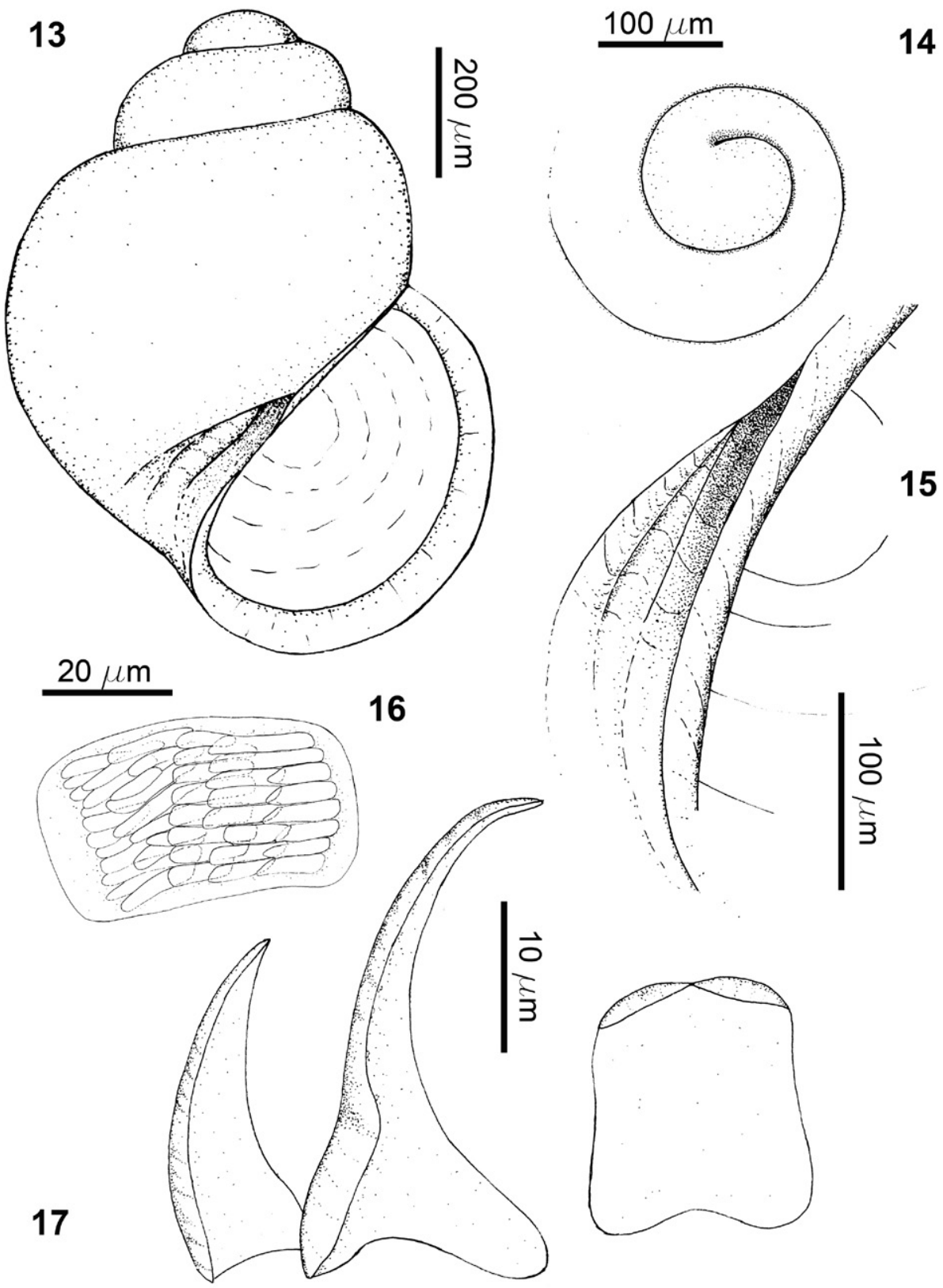

Figures 13-17. Rissoella morrocoyensis sp. n.: shell (I3), protoconch (I4), detail of the umbilicus (I5), odontophoral cartilages (I6), radular teeth (I7).

$\mathrm{mm}$ and $1 \mathrm{~mm} \times 0.69 \mathrm{~mm}$, preserved in etanol 96\%, SOM-IVIC (IVICCMT006). Paratypes 3-4, $1.16 \mathrm{~mm} \times 0.80 \mathrm{~mm}$ and $1.06 \mathrm{~mm} \times 0.82 \mathrm{~mm}$, preserved dry, SOMIVIC (IVICCMT007). Paratypes 5-7, $0.90 \mathrm{~mm} \times 0.68 \mathrm{~mm} ; 0.86 \mathrm{~mm} \times 0.78 \mathrm{~mm}$ and $1.10 \mathrm{~mm} \times 0.80 \mathrm{~mm}$, preserved dry, FUDENA (CFPM0001). 
Table 2. Rissoella morrocoyensis sp. n. Measurements of specimens. (\%) means percentage compared to the total length of the shell.

\begin{tabular}{l|c|c|c|c}
\hline & $\begin{array}{c}\text { Protoconch } \\
(\mathbf{w h o r l s})\end{array}$ & $\begin{array}{c}\text { Last whorl } \\
(\mathbf{m m})\end{array}$ & $\begin{array}{c}\text { Aperture } \\
(\mathbf{m m})\end{array}$ & Length /width \\
\hline Holotype & & & & \\
\hline $1.06 \times 0.82 \mathrm{~mm}$ & 1.5 & $0.92(87 \%)$ & $0.64(60 \%)$ & 1.29 \\
\hline Paratypes & - & - & - & 1.45 \\
\hline $1-1.25 \times 0.86 \mathrm{~mm}$ & - & - & - & 1.44 \\
\hline $2-1 \times 0.69 \mathrm{~mm}$ & 1.25 & $0.92(79 \%)$ & $0.70(60 \%)$ & 1.45 \\
\hline $3-1.16 \times 0.80 \mathrm{~mm}$ & 1.15 & $0.90(85 \%)$ & $0.64(60 \%)$ & 1.29 \\
\hline $4-1.06 \times 0.82 \mathrm{~mm}$ & 1 & $0.80(89 \%)$ & $0.54(60 \%)$ & 1.32 \\
\hline $5-0.90 \times 0.68 \mathrm{~mm}$ & 1.5 & $0.76(88 \%)$ & $0.58(67 \%)$ & 1.10 \\
\hline $6-0.86 \times 0.78 \mathrm{~mm}$ & 1.25 & $0.92(84 \%)$ & $0.66(60 \%)$ & 1.37 \\
\hline $7-1.10 \times 0.80 \mathrm{~mm}$ & & & & \\
\hline Further $\mathbf{m a t e r i a l}$ & 1 & $0.85(83 \%)$ & $0.57(56 \%)$ & 1.18 \\
\hline $1.02 \times 0.86 \mathrm{~mm}$ & - & - & 0.46 & 1.31 \\
\hline $0.92 \times 0.70 \mathrm{~mm}$ & & $\mathbf{8 5 \%}$ & $\mathbf{6 0 \%}$ & $\mathbf{1 . 3 2}$ \\
\hline Average & - & & &
\end{tabular}

Further material. $1.02 \mathrm{~mm} \times 0.86 \mathrm{~mm}$, collected (March 24, 2010) in Boca Grande, PNM $\left(10^{\circ} 51^{\prime} 01.71 " \mathrm{~N}, 68^{\circ} 14^{\prime} 16.48^{\prime \prime W}\right)$, used to obtain the radula, therefore the specimen was destroyed.

Type locality. Boca Grande, National Park Morrocoy, Venezuela (1051'28.85"N, $\left.68^{\circ} 13^{\prime} 17.04^{\prime \prime} \mathrm{W}\right)$, at the base of the leaves of Thalassia testudinum, $1 \mathrm{~m}$ depth.

Etymology. morrocoyensis, latinization of morrocoy, place name of National Park Morrocoy, Venezuela, where the type locality is located.

Remarks. According to the classification given by Ortea and Espinosa (2004), $R$. morrocoyensis sp. n. would cluster within the Caribbean species group with a preumbilical cord, which include: Rissoella zaidae Ortea \& Espinosa, 2004 (Fig. 27), Rissoella florae Ortea \& Espinosa, 2004 (Fig. 28), Rissoella elsae Ortea \& Espinosa, 2004 (Fig. 29) and Rissoella taniae Ortea \& Espinosa, 2004 (Fig. 30). R. morrocoyensis sp. $n$. has a preumbilical cord thicker than these four species, all of which have their type locality on the shores of Cuba. Additionally, the body colouration of $R$. florae, $R$. elsae and $R$. taniae is very different as well as the shape and proportions of their shells, which are larger.

The shell of $R$. zaidae is similar in size to that of $R$. morrocoyensis sp. n., but the animal has a different colour and the oral palps equal the cephalic tentacles, while in $R$. morrocoyensis sp. $\mathrm{n}$., they are shorter. Additionally, $R$. zaidae has transverse yellow bands in the hypobranchial gland.

Rissoella contrerasi Rolan \& Hernandez, 2004, from Africa, has the design on the hypobranchial gland similar to $R$. morrocoyensis sp. n., but it distinguishes by the curved inner edge of the columella, by the oral lobes being longer than the cephalic tentacles, 
and by it's different body colour (black), which is displayed even on the sole of the foot and on the hypobranchial gland. In addition, the whorls of the shell and the aperture are different and it has a wider umbilicus.

\section{Rissoella venezolanicola sp. $\mathbf{n}$.}

urn:lsid:zoobank.org:act:69FA6D90-9365-4ADD-92DA-820BC27EC917

http://species-id.net/wiki/Rissoella_venezolanicola

Figs 6-8, 11-12, 18-22, Tabs 1, 3, 4

Description. Shell very small (Tab. 3), smooth and translucent (Fig. 18); protoconch about half a whorl after the nucleus (Fig. 19); teleoconch of two whorls and three quarters; aperture oval, with the columella slightly bowed and arched; umbilicus narrow and deep, slightly closed by the expansion of the columellar edge; preumbilical cord extended, with an angle delimiting and closing the umbilicus forming a trapezoid (Figs 11-12, 20); average height of the last whorl, $82.9 \%$ of shell length; average height of the aperture, $49.6 \%$ of shell length (Tab. 3); Shell length/width ratio $=1.52$; spiral angle $=58^{\circ}$; umbilical angle $=23^{\circ}-25^{\circ}$.

Operculum oval, translucent with an amber tinge, membranous consistence; head, flanks, oral lobes and cephalic tentacles translucent white with scattered black to greenish brown dots (Fig. 6); eyes black; foot translucent white (Fig. 7); hypobranchial gland translucent white with scattered blotches black to greenish brown and a distinctive yellow design quaver-shaped (Fig. 8); visceral mass in the first whorls, black; protoconch with fuchsia highlights in live animals.

Odontophoral cartilages kidney-shaped, with large uncini placed longitudinally (Fig. 21); radular formula of an specimen $0.96 \mathrm{~mm}$ shell length, $16 \times 1.1$.R.1.1; rachidian tooth wide, with bilobed apex forming two smooth cusps (Fig. 22), slightly larger than marginal tooth; lateral tooth triangular, $28.3 \mu \mathrm{m}$ long, with the apex hooked and smooth; imbricated with the opposite tooth above the rachidian; marginal tooth triangular and curved, $16.3 \mu \mathrm{m}$ long, with blunt apex.

Types. Holotype, $1.02 \mu \mathrm{m} \times 0.66 \mu \mathrm{m}$, collected alive (August 2, 2010), preserved dry and deposited in FUDENA (CFRFSIA0002). Paratype 1, $0.96 \times 0.64 \mu \mathrm{m}$, SOMIVIC (IVICCMT008), used to get the radula, shell preserved dry. Paratype 2, $0.54 \times$ $0.46 \mu \mathrm{m}$, preserved dry, SOM-IVIC (IVICCMT009).

Type locality. Leeward patch reef, Isla de Aves, Venezuela (15³9'54.2"N, 633'17.6"W), on Dictyota spp., $10 \mathrm{~m}$ depth.

Further localities. Paratypes: Northern end, Isla de Aves, Venezuela, $\left(15^{\circ} 40^{\prime} 24.7^{\prime \prime} \mathrm{N}\right.$, $\left.63^{\circ} 37^{\prime} 11^{\prime \prime W}\right)$, on Dictyota spp., $10 \mathrm{~m}$ depth.

Etymology. venezolanicola latinization of venezolana, inhabitant of Venezuela.

Remarks. Due to the presence of the preumbilical cord, $R$. venezolanicola sp. n., is comparable to $R$. zaidae, $R$. florae, $R$. elsae, $R$. taniae (Ortea and Espinosa 2004) (listed above) and $R$. morrocoyensis sp. $\mathrm{n}$. But it is different because in none of them the preumbilical cord delimits and closes the umbilicus, neither the hypobranchial gland 


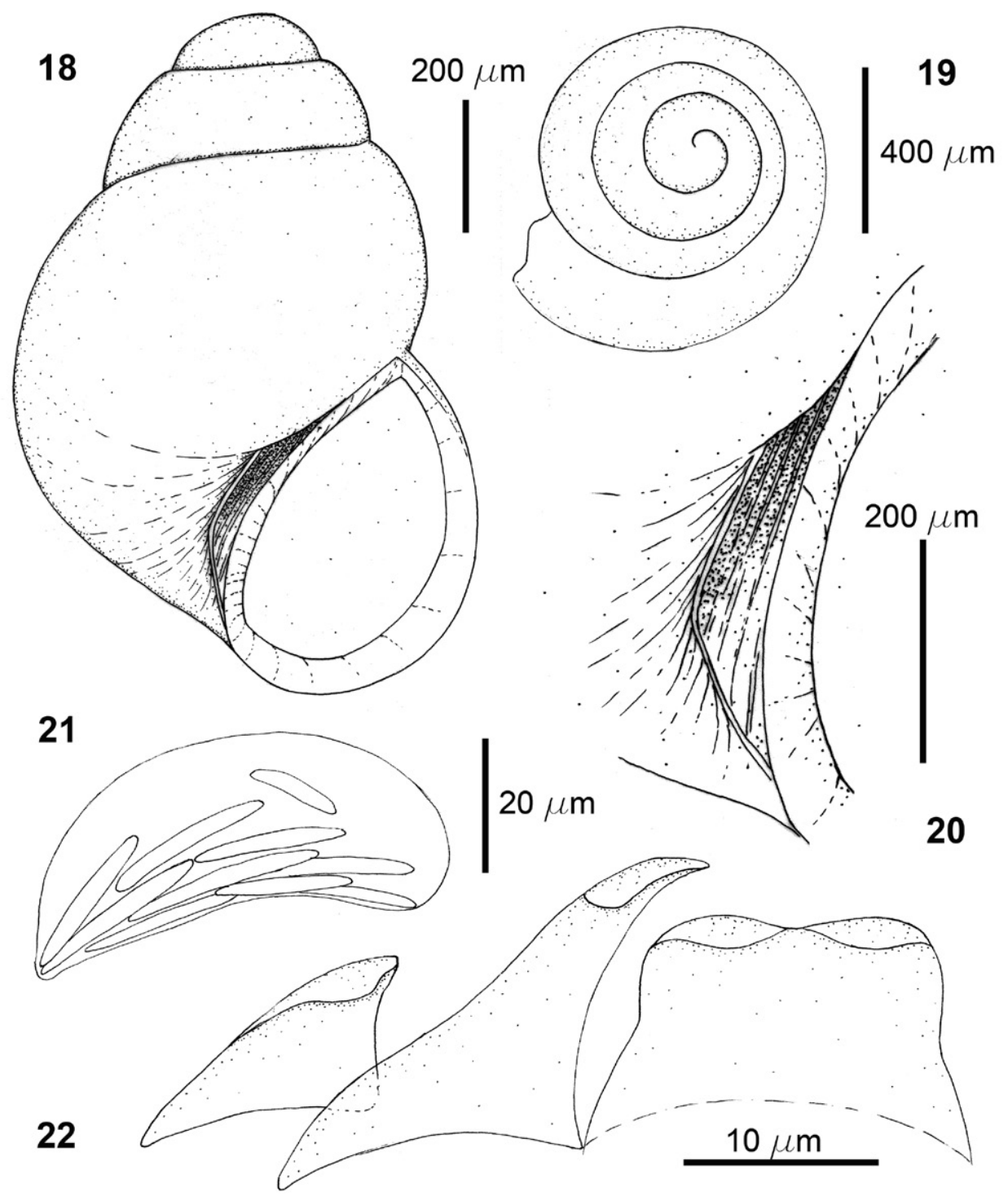

Figures 18-22. Rissoella venezolanicola sp. n.: shell (18), protoconch (19), detail of the umbilicus (20), odontophoral cartilages (2I), radular teeth (22).

has a yellow quaver-shaped design. Additionally, $R$. venezolanicola sp. $\mathrm{n}$. differs from all these species by:

- $\quad$ R. $z$ aidae: (shell length $/$ width ratio $=1.63$, spiral angle $=50^{\circ}$, umbilical angle $=30^{\circ}$ ) the whorls of the spire are more angled and tilted, the umbilicus is in the middle of the last whorl, the head, oral lobes, cephalic tentacles and the visceral mass in the first whorls are lilac and the hypobranchial gland is kidney- 
Table 3. Rissoella venezolanicola sp. $n$. Measurements of specimens. (\%) means percentage compared to the total length of the shell.

\begin{tabular}{l|c|c|c|c}
\hline & $\begin{array}{c}\text { Protoconch } \\
(\mathbf{w h o r l s})\end{array}$ & $\begin{array}{c}\text { Last whorl } \\
(\mathbf{m m})\end{array}$ & $\begin{array}{c}\text { Aperture } \\
(\mathbf{m m})\end{array}$ & Length /width \\
\hline Holotype & & & & \\
\hline $1.02 \times 0.66 \mathrm{~mm}$ & 1.25 & $0.82(80 \%)$ & $0.46(45 \%)$ & 1.54 \\
\hline Paratypes & & & & \\
\hline $0.96 \times 0.64 \mathrm{~mm}$ & 1.25 & $0.80(83 \%)$ & $0.52(54 \%)$ & 1.50 \\
\hline $0.54 \times 0.46 \mathrm{~mm}$ & 1.5 & $0.46(85 \%)$ & $0.38(70 \%)$ & 1.18 \\
\hline Average & & $\mathbf{8 3} \%$ & $* \mathbf{5 0} \% \mathbf{5 7 \%}$ & $* \mathbf{1 . 5 2 / 1 . 4}$ \\
\hline
\end{tabular}

* Excluding the juvenile specimen.

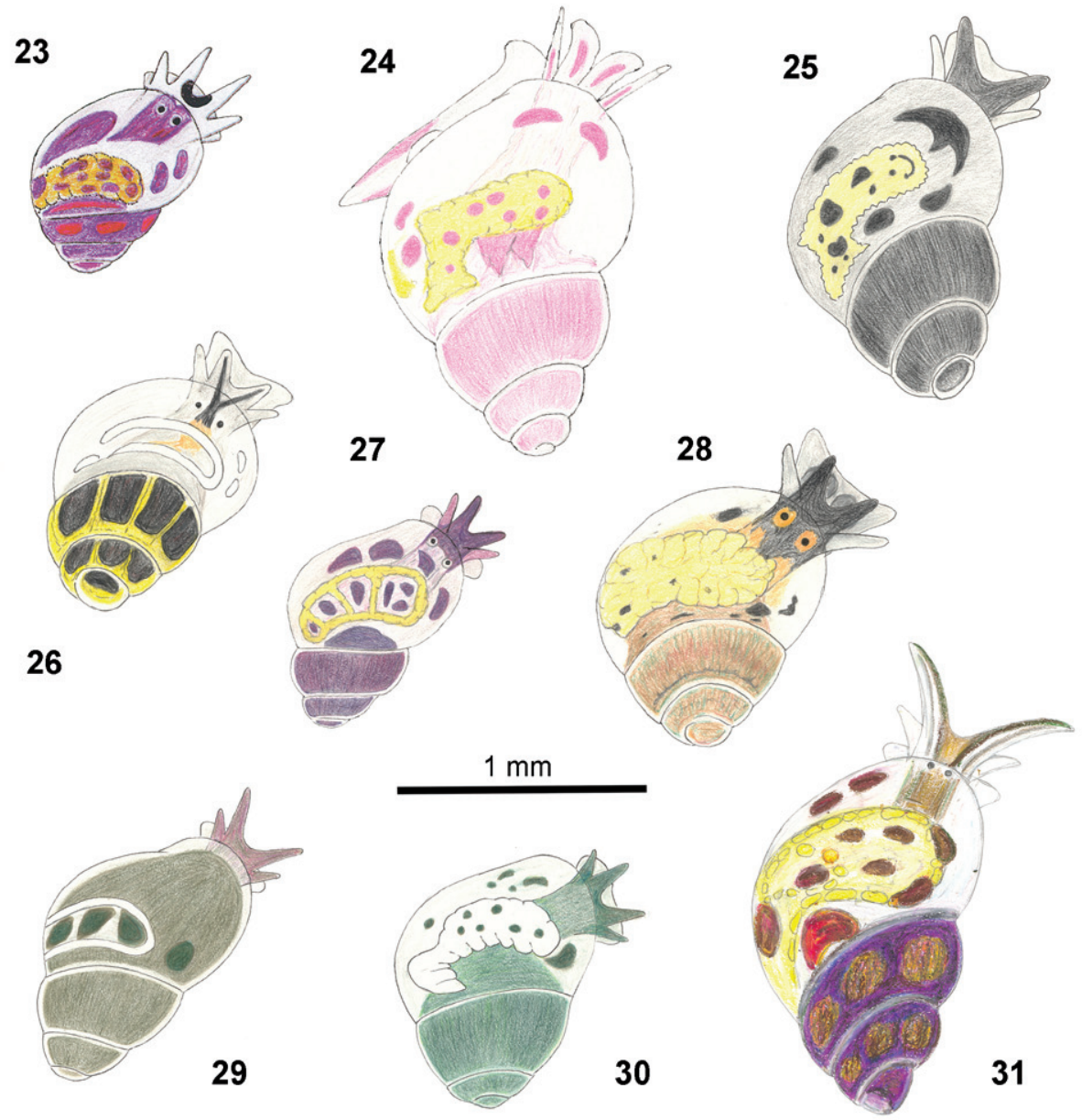

Figures 23-3 I. Color illustrations adapted from the original descriptions (Ortea and Espinosa 2001; 2004; Espinosa and Ortea 2009). $R$. gandocaensis (23), $R$. ameliae (24), $R$. belkisae (25), $R$. dianae (26), $R$. zaidae (27), $R$. florae (28), $R$. elsae (29), $R$. taniae (30), $R$. aliciae (3I). 


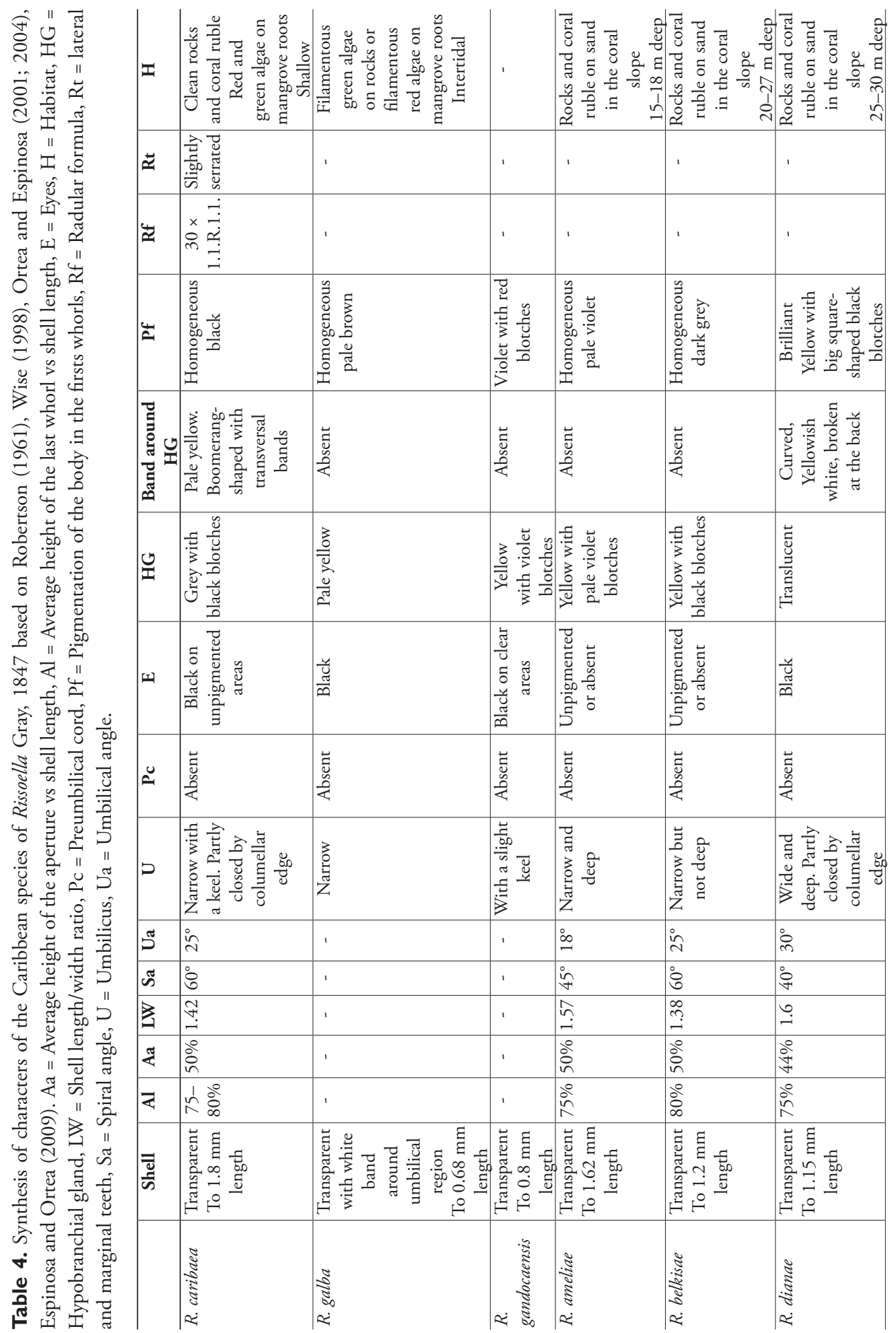




\begin{tabular}{|c|c|c|c|c|c|c|c|}
\hline 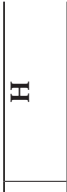 & 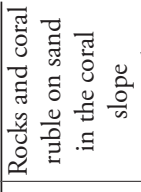 & 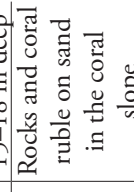 & 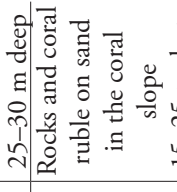 & 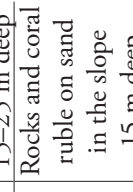 & 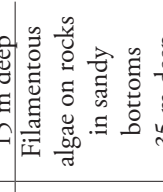 & 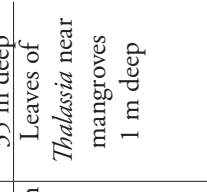 & 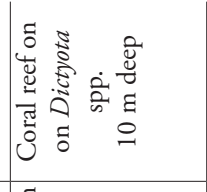 \\
\hline$\vec{\approx}$ & & ' & 1 & ' & & 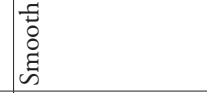 & हू \\
\hline$\ddot{\Xi}$ & & . & ' & ' & ' & 亲 & 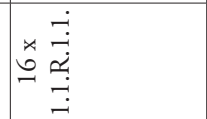 \\
\hline$\ddot{\Xi}$ & 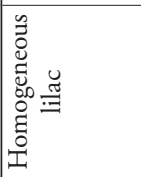 & 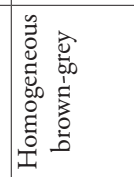 & 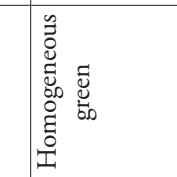 & 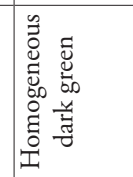 & 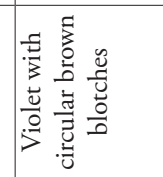 & 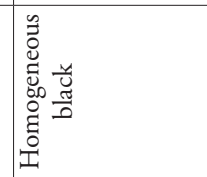 & 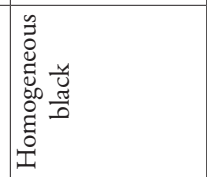 \\
\hline 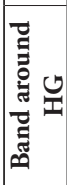 & 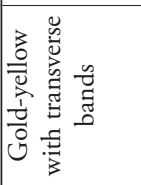 & 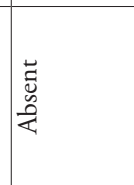 & 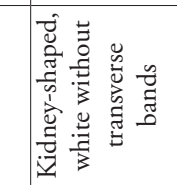 & 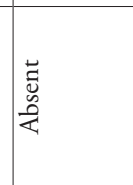 & 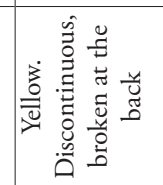 & 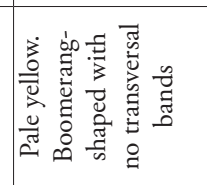 & 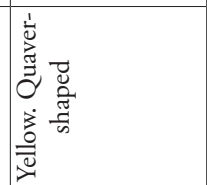 \\
\hline שي & 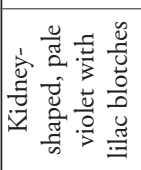 & 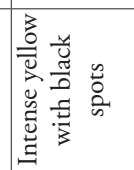 & 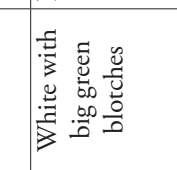 & 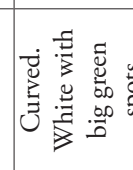 & 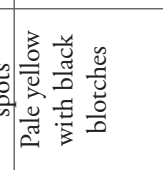 & 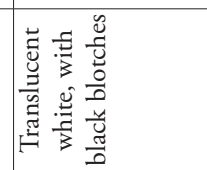 & 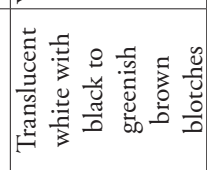 \\
\hline Ir & 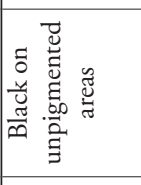 & 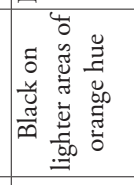 & 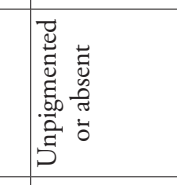 & 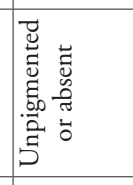 & 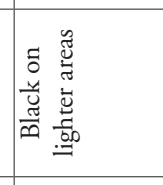 & 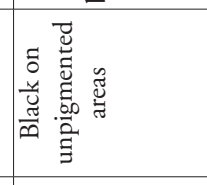 & 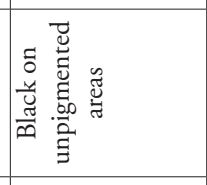 \\
\hline 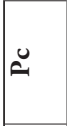 & 苞 & 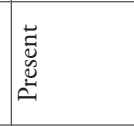 & 蒙 & 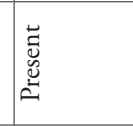 & 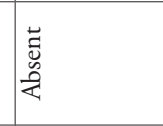 & 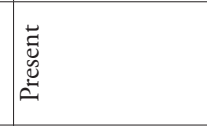 & 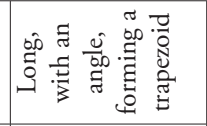 \\
\hline$p$ & 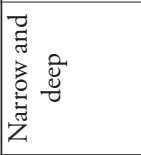 & 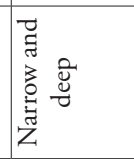 & 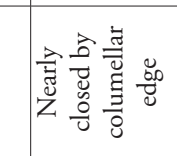 & $\frac{\tilde{g}}{\bar{v}}$ & 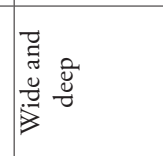 & 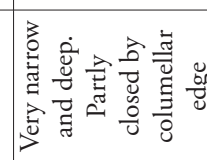 & 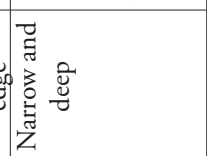 \\
\hline 5 & 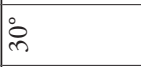 & $\cong$ & $i$ & $\dddot{q}$ & సं & $\frac{1}{\sim} \stackrel{\infty}{\sim} \stackrel{\infty}{\sim}$ & $\stackrel{i}{i}_{i j}^{i}$ \\
\hline nீ & $\stackrel{\circ}{i}$ & : & if & in & if & : & $\stackrel{\infty}{\infty}$ \\
\hline 8 & త్ర & $\stackrel{\sim}{\rightarrow}$ & ל요 & $\stackrel{H}{H}$ & $\stackrel{\sim}{2}$ & בีב్తి & $\stackrel{1}{2}$ \\
\hline \& & 离 & $\stackrel{\circ}{n}$ & 商 & ঐें & 吕 & 8̊̀ & $\begin{array}{l}\circ \\
\text { in }\end{array}$ \\
\hline « & 品 & $\stackrel{\circ}{\grave{n}}$ & §̊ & 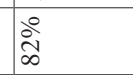 & $\frac{8}{0}$ & $\stackrel{\circ}{\circ}$ & $\stackrel{\infty}{\infty}$ \\
\hline 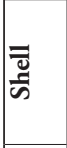 & 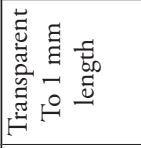 & 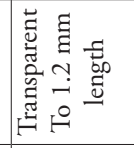 & 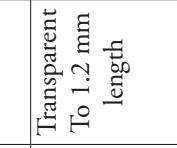 & 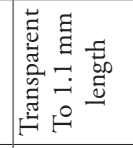 & 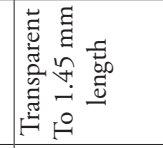 & 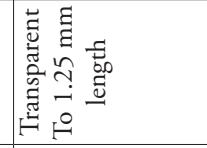 & 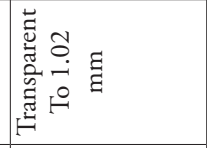 \\
\hline & $\mid$ & $\frac{\pi}{3}$ & 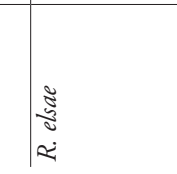 & 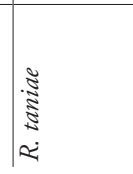 & 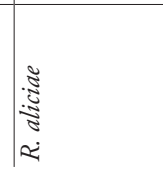 & 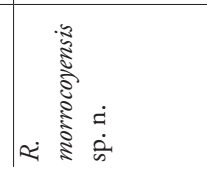 & 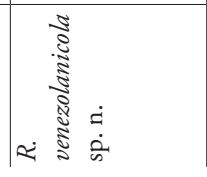 \\
\hline
\end{tabular}


shaped, pale violet with lilac blotches and bounded by a yellow ribbon with transverse bands.

- $\quad$ R. florae: $\left(\right.$ shell length $/$ width ratio $=1.35$, umbilical angle $\left.=18^{\circ}\right)$ the head and oral lobes are black, the cephalic tentacles are different in colour than the oral lobes, the eyes are located in lighter areas of orange hue, the visceral mass in the first whorls is brown or orange and the hypobranchial gland is lemon-yellow without any design on it.

- R. elsae: $\left(\right.$ shell length $/$ width ratio $=1.69$, spiral angle $=45^{\circ}$ ) the shell is more conical, the preumbilical cord is higher than the columellar wall, the head, oral lobes and cephalic tentacles are lilac, the mantle is green and hides the eyes, and the hypobranchial gland has large patches of dark green and is enclosed by a white ribbon with transverse bands.

- $\quad R$. taniae: (shell length $/$ width ratio $=1.4$, spiral angle $=65^{\circ}$, umbilical angle $=43^{\circ}$ ) the shell is spherical with slightly globose whorls, the umbilicus is very open, the head, oral lobes, cephalic tentacles and visceral mass in the first whorls are dark green, there are no eyes apparently and the hypobranchial gland is white with green spots.

- $\quad$ R. morrocoyensis sp. n.: (shell length/width ratio $=1.32$ ) the umbilicus is deeper and more closed by the expansion of the columellar edge and the head, oral lobes and cephalic tentacles are black.

Two species from Africa have a design on the hypobranchial gland similar to $R$. venezolanicola sp. n.: Rissoella luteonigra Rolan \& Rubio, 2001 and Rissoella trigoi Rolan \& Hernández, 2004. R. venezolanicola sp. $n$. differs from these species in:

- $\quad R$. luteonigra; is bigger $(1.8 \mathrm{~mm})$, with a narrower and longer shell, lacking preumbilical cord. Animals are black homogeneous (Rolan and Rubio 2001).

- $\quad$ R. trigoi; has a rough protoconch with cavities in the suture, the preumbilical cord parallel to the expansion of the columellar edge until it converges (divergent in $R$. venezolanicola sp. $n$.) and the animals are black with a white drawing in the hypobranchial gland (Rolan and Hernández 2004), very simple and very different.

\section{Discussion}

The species of the family Rissoellidae are difficult to study and to identify, because their small transparent shells have only a few characters. Thus, identification should also be based on the color patterns of the animals facilitating correct recognition (Sasaki, 2008). The lack of consensus on the correct characters to segregate species could explain why it is one of the least studied families of micromolluscs (Okutani 2000). For example in Japan, which is a country with a long malacological tradition, there are at least 10 morphospecies known, but most of them yet undescribed (Hasegawa 2000). 
Species from this family belonging to the genus Rissoella have low dispersal abilities because of the absence of a pelagic larval stage. They are usually found in very specific habitats (Ortea and Espinosa 2004) and they tend to be microendemic, although their small size could facilitate passive transport in floating elements covered by algae. Therefore, their distribution should be established solely on the basis of publications that provide sufficient data for unambiguous identification. Concluding from this, most of the historical records of Rissoella species in Western Atlantic have to be considered doubtful.

In the Caribbean Sea, $R$. caribaea is the most controversial species with the widest known distribution (Ortea and Espinosa 2004). The original description of $R$. caribaea by Rehder (1943) did not allow to distinguish it from other species of the genus in the West Atlantic, but Wise (1998) compared his specimens from Florida with the holotype of this species (USNM No. 536046) and published a detailed redescription. According to him, $R$. caribaea has a deep and narrow umbilicus without preumbilical cord, several strands or streaks of uniform height leaving from the umbilicus, a characteristic and prominent keel, bifid nose, gray-black body and hypobranchial gland, the last surrounded by a yellow ribbon with transverse bands, and a radula with 30 rows of serrated teeth. Although there is some theoretical geographic overlap, these characters clearly separate it from $R$. morrocoyensis sp. n. and $R$. venezolanicola sp. n.

$R$. caribaea has been cited from:

- $\quad$ Florida (type locality).

- $\quad$ Florida, Bahama and Puerto Rico by Robertson (1961), who interprets the large differences in shell, body color and habitat along its distribution as intraspecific variation.

- $\quad$ Puerto Rico by Ortiz-Corps (1985) just as a compilation of references.

- $\quad$ Florida to Puerto Rico by Abbott (1974), with a description and figures.

- Curaçao by Jong and Coomans (1988), based on the species description given by Abbott (1974).

- $\quad$ Mexico by Vokes and Vokes (1983), with a black and white photograph that doesn't permit to distinguish this species.

- Northern Brazil, where Rios (1994) reproduced the same image that appeared in Abbott's book (1974).

- Bahamas by Redfern (2001), with images of the shell and the live animal. Curiously, the shell shown lacks the characteristic keel of the species shown by Wise (1998).

- $\quad$ Nicaragua by Rolan and Hernández (2004) in the legend of an illustration.

- $\quad$ Mexico by Felder and Camp (2009), on a checklist based on Vokes and Vokes (1973), Wise (1998) and Hicks et al. (2001).

- Venezuela by Bitter et al. (2009), in a table without anatomic confirmation nor supply of images of the shell or the animal body.

- $\quad$ Puerto Rico, Mexico, Belize and Aruba-Bonaire-Curaçao by Miloslavich et al. (2010) in a checklist of previous records. 
Most of these authors repeat previous records (mainly Abbott's), but very few of them give anatomical data or useful images to distinguish the species. Therefore, we consider it more likely that the real distribution of $R$. caribaea is that given by Abbott (1974), from Florida to Puerto Rico. All other records require anatomical confirmation.

The record of Bitter et al. (2009) probably refers to $R$. morrocoyensis sp. n. because of the proximity to its type locality.

R. galba (Tab. 4) is a very rare and characteristic species (Robertson 1961), which has been cited from:

- $\quad$ Bahama Islands (type locality) in low abundance cohabiting with hundreds of R. caribaea (Robertson 1961).

- Cozumel Island (Mexico) by Moore (1973), from shells in sediments, on a checklist without data or images.

- $\quad$ Puerto Rico by Ortiz-Corps (1985) just as a compilation of references.

- Bahamas (Abaco) by Redfern (2001), who only got a few empty shells in sediments from 10 to $23 \mathrm{~m}$ depth.

Abbott (1974) considers this species endemic for the Bahama Islands, we agree with this statement. Specimens from Mexico and Puerto Rico possibly refer to a related but undescribed species.

$R$. ornata has been recorded from the coasts of Yucatan (Mexico) by Rolan and Hernández (2004), but their specimens are different from the species of Simone (1995) (Ortea and Espinosa 2004). So, the record in the Caribbean for R. ornata, whose type locality is in southern Brazil, is considered to represent a misindentification.

None of the species of Rissoella described by Ortea and Espinosa $(2001 ; 2004)$ and Espinosa and Ortea (2009) has been recorded from outside Cuba or Costa Rica, respectively. A synthesis of their main characters based on the original descriptions is shown in Figs 23-31 and Tab. 4.

This is the second record of species of the genus Rissoella for Venezuela and the mainland of the southern Caribbean, the first confirmed by anatomical characters. Thus, the the list of valid species in the Caribbean is now raised to 13 (Tab. 1). Even when the number of species of the genus in the Caribbean is likely to increase with future targeted searches and the exploration of new areas, a key is provided to allow the user to distinguish whether their specimens are already described or not.

In conclusion, we suggest that information on additional characters should be supplied when describing and characterising species of the genus Rissoella in the Caribbean. At least, detailed descriptions of the umbilicus (preumbilical cord, keel) displayed by line drawings or SEM photos, and colour illustrations of the living animals (including observations on the presence/absence and shape of the band around the hypobranchial gland) are urgently needed for an unambiguous identification. 


\section{Key to the Rissoella species known from the Caribbean}

$1 \quad$ Shell with wide umbilicus. No preumbilical cord ..................................... 2

- Shell with preumbilical cord in the umbilicus ........................................... 8

2 Gonad and digestive gland of uniform colouration in the first whorls ........ 3

- $\quad$ Gonad and digestive gland with different colouration in the first whorls......6

3 Shell with an opaque white spiral band extending around de umbilical region

R. galba

$-$

Shell lacking a white band around de umbilical region. Hypobranchial gland surrounded by a yellow ribbon kidney-shaped, with transverse bands.

R. caribaea

Hypobranchial gland not surrounded by a ribbon

5

Oral lobes same color than the cephalic tentacles. Hypobranchial gland yellow with pink/violet blotches. Pink head

R. ameliae

Oral lobes different in color than the cephalic tentacles. Hypobranchial gland yellow with black blotches. Dark grey or black head

R. belkisae Hypobranchial gland not conspicuous, surrounded by a discontinuous pale band, interrupted around the perimeter. White operculum. R. dianae Hypobranchial gland conspicuous and yellow.... 7

Hypobranchial gland surrounded by a yellow ribbon kidney-shaped, without transverse bands..... R. aliciae

Eyes present and visible Hypobranchial gland white with green blotches, surrounded by a white ribbon kidney-shaped, without transverse bands. Lilac head. R. elsae Hypobranchial gland white, not surrounded by a ribbon. Green head

R. tainae Hypobranchial gland surrounded by a band or with a design 11 Hypobranchial gland intense yellow, not surrounded by a ribbon. Eyes in lighter areas of orange hue

R. florae Hypobranchial gland translucent white, surrounded by a yellow quavershaped ribbon $R$. venezolanicola Hypobranchial gland violet with lilac blotches, surrounded by a gold-yellow band with transverse bands R. zaidae

- Hypobranchial gland translucent white, surrounded by a pale yellow band without transverse bands. R. morrocoyensis 


\section{Acknowledgements}

We are in debt to our friend and colleague Manuel Malaquias (Bergen Museum) for his help in the field in the campaign in Venezuela, and to Lorenzo A. Álamo (IVIC) for the assistance with optical microscopy. To Philippe Bouchet, P. Maestrati, V. Héros and B. Buge (Biodiversity Exploration Unit, Muséum National d'Histoire Naturelle), for his kindness and help in Paris. To Gelín Mejías and Samuel García, from the Electron Microscopy Center, Faculty of Engineering, Central University of Venezuela. To Gonzalo Medina for the pictures of living specimens from Isla de Aves. To the Armada Bolivariana de Venezuela, for all the effort in promote the scientific research in Isla de Aves and to the Naval Scientific Base "Simón Bolívar" in Isla de Aves for the logistics of the expeditions and their hospitality. This work has been partially funded by the IVIC project 915 - Marine biodiversity in Venezuela and its relationship with coastal dynamics. Molluscs as focal group and source of new molecules.

\section{References}

Abbott RT (1974) American seashells, second edition. Van Nostrand Reinhold Company, New York, $663 \mathrm{pp}$.

Bitter R, Didonna G, Vieitez JM (2009) Caracterización de la comunidad de moluscos asociada

a Thalassia testudinum en localidades del Parque Nacional Morrocoy, Venezuela. Ciencia 17 (2): 151-168.

Espinosa J, Ortea J (2009) Nueva especie de Rissoella J.E. Gray, 1847 (Gastropoda: Heterobranchia) de la Península de Guanahacabibes, Pinar del Río, Cuba. Revista de la Academia Canaria de Ciencias XX (4): 15-17.

Felder DL, Camp DK (2009) Gulf of Mexico: origin, waters, and biota. Volume 1. Biodiversity. Texas A\&M University Press, Texas, 1312 pp.

Hasegawa K (2000) Family Rissoellidae. In: Okutani T (Ed) Marine Mollusks in Japan. Tokai University Press, Tokyo, 1174 pp.

Hicks DW, Barrera NC, Tunnel JW (2001) Ecological distribution of shallow-water mollusca on the Alacrán Reef, Campeche Bank, Yucatan, Mexico. Texas Conchologist 38 (1): 7-30.

Jong RM, Coomans HE (1988) Marine gastropods from Curaçao, Aruba and Bonaire. Studies on the Fauna of Curaçao and other Caribbean Islands 214: 1-261.

Miloslavich P, Díaz JM, Klein E, Alvarado JJ, Díaz C, Gobin J, Escobar-Briones E, Cruz-Mota JJ, Weil E, Cortes J, Bastidas AC, Robertson R, Zapata F, Martin A, Castillo J, Kazandjian A, Ortiz M (2010) Marine biodiversity in the Caribbean: regional estimates and distribution patterns. PLoS ONE 5 (8): e11916. doi: 10.1371/journal.pone.0011916. 
Moore DR (1973) Mollusks from a small landlocked Mexican lagoon. Bulletin of the American Malacological Union 1972: 5-6.

Okutani T (2000) Marine Mollusks in Japan. Tokai University Press, Tokyo, 1174 pp.

Ortea J, Espinosa J (2001) Descripción de una nueva especie del género Risoella Gray, 1847. In: Espinosa J, Ortea J (Eds) Moluscos del mar Caribe de Costa Rica. Avicennia supplement 4, 36.

Ortea J, Espinosa J (2004) Una combinación de ciencia, arte y naturaleza: especies nuevas del género Rissoella J. E. Gray, 1847 (Gastropoda, Heterobranchia) descritas en homenaje a las artistas de la plástica cubana. Avicennia 17: 77-94.

Ortiz-Corps EAR (1985) An annotated checklist of the recent marine Gastropoda (Mollusca) from Puerto Rico. In: Memorias del Sexto Simposio de la Fauna de Puerto Rico y el Caribe. University of Puerto Rico, Humacao, Puerto Rico, 45.

Ponder WF, Yoo EK (1977) A revision of the Australian species of Rissoellidae Mollusca: Gastropoda). Records of the Australian Museum 31 (4): 133-185. doi: 10.3853/j.00671975.31.1977.208

Redfern C (2001) Bahamian Seashells: a thousand species from Abaco, Bahamas. Bahamianseashells.com, Inc., Boca Raton, Florida, 280 pp.

Rehder HA (1943) New marine mollusks from de Antillean Region. Proceedings of the United States National Museum, 93 (3161): 187-205.

Rios E (1994) Seashells of Brazil (second edition). Museu Oceanográfico da Fundaçao Universidade do Rio Grande, Rio Grande, Brazil, 492 pp.

Robertson R (1961) A second Western Atlantic Rissoella and a list of the species in the Rissoellidae. The Nautilus 74: 131-136.

Rolán E, Hernández JM (2004) Dos nuevas especies de Rissoella (Mollusca: Rissoellidae) de las islas Canarias y Senegal. Revista de la Academia Canaria de Ciencias XV (3-4): 229-235.

Rolán E, Rubio F (2001) New species of the genera Elachisina and Rissoella (Mollusca, Gastropoda) from the Cape Verde Archipelago. Novapex 2 (4): 133-136.

Sasaki T (2008) Micromolluscs in Japan: taxonomic composition, habitats, and future topics. Zoosymposia 1: 147-232.

Simone LR (1995) Rissoella ornata, a new species of the family Rissoellidae (Mollusca: Gastropoda: Rissoelloidea) from the southeastern coast of Brazil. Proceedings of the Biological Society of Washington 108 (4): 560-567.

Vokes HE, Vokes EH (1983) Distribution of shallow-water marine mollusca, Yucatan Peninsula, Mexico. Mesoamerican Ecology Institute Monograph 1. Middle American Research Institute Publication, 54, Tulane University, New Orleans, 183 pp.

Wise JB (1998) Morphology and systematic position of Rissoella caribaea Rehder, 1943 (Gastropoda: Heterobranchia: Rissoellidae). The Nautilus 111 (1): 13-21. 